\title{
RADIO-ECHO INVESTIGATIONS OF RONNE ICE SHELF
}

\author{
by
}

\author{
R.D. Crabtree and C.S.M. Doake
}

(British Antarctic Survey, Natural Environment Research Council, High Cross, Madingley Road, Cambridge CB3 OET, UK)

\section{ABSTRACT}

Since 1981, the British Antarctic Survey has flown 27000 line kilometres over Ronne Ice Shelf, during which radio-echo ice thicknesses were recorded. An earlier map of ice thickness was compiled from about $5000 \mathrm{~km}$ of flight lines, flown by three different organisations over a period of 12 years. A new, detailed map of the thickness of Ronne Ice Shelf has been produced, which agrees with the earlier version, but shows more structure in the north-western part. In particular, major ice streams maintain their identity from sources such as Evans and Rutford ice streams all the way to the ice front. Regions where the ice shelf is locally grounded over Kershaw Ice Rumples and over more extensive ice rumples between Korff and Henry ice rises play a significant role in controlling the dynamics of the ice shelf. There is a possibility of extensive freezing-on of sea water under the thin, central section of Ronne Ice Shelf, although the radio-echo evidence for a thick layer of saline ice is ambiguous.

\section{INTRODUCTION}

Ronne Ice Shelf is the second largest ice shelf in Antarctica (Fig.1). Together with Filchner Ice Shelf, it forms the world's greatest mass of floating Ice Shelf, it forms the world's greatest mass of floating ice with a volume of $307 \times 10^{3} \mathrm{~km}^{3}$, compared with $224 \times 10^{3} \mathrm{~km}^{3}$ for the Ross Ice Shelf (Drewry and others, 1982). Although it drains an area estimated at $1200 \times 10^{3} \mathrm{~km}^{2}$, compared with $1800 \times 10^{3} \mathrm{~km}^{2}$ for Filchner Ice Shelf, it is about three times the size of its neighbour. Its catchment lies predominantly within higher accumulation areas in West Antarctica and it mass flux, at the ice front, of $138 \mathrm{~km}^{3} \mathrm{a}^{-1}$ is much greater than that for Filchner Ice Shelf $\left(82 \mathrm{~km}^{3} \mathrm{a}^{-1}\right)$ and comparable with the larger, but thinner, Ross Ice Shelf $\left(150 \mathrm{~km}^{3} \mathrm{a}^{-1}\right)$ (Doake, 1985).

A considerable portion of the West Antarctic Ice Sheet, draining into Ronne Ice Shelf, lies on bedrock below

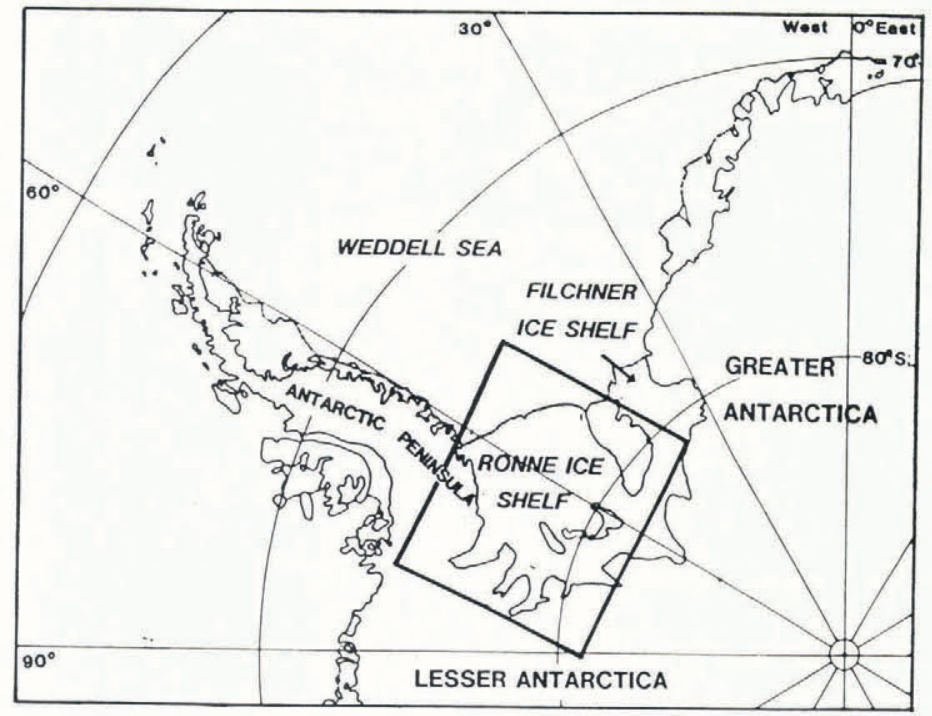

Fig.1. The Antarctic Peninsula, Ronne and Filchner ice shelves. The area within the rectangle is that covered in Figs, 2, 3 and 4 . sea-level (Jankowski and Drewry, 1981; Doake and others, 1983). The position and stability of the grounding line are determined by the interaction between driving stress related to ice thickness, on the one hand, and restraint caused by friction, on the other. Restraint can be caused by lateral shear along the edges of the ice shelf, or by grounding of the ice over elevated regions of the sea floor. Some $1.9 \%$ of Ross Ice Shelf is grounded in this way, but the figure for Ronne Ice Shelf is $3.4 \%$, almost double. These grounded areas, two of which are fully developed ice rises, are strung out across the southern part of the ice shelf in such a way that they impede flow over $50 \%$ of its width.

Data from all the surveys up to 1981, plus ice thickness measurements obtained by radio altimeters mounted in TWERLE balloons were used to produce the first comprehensive map of ice thickness over Ronne and Filchner ice shelves (Robin and others, 1983). Since this map was compiled, there has been an increase in geophysical research in this area (Kohnen, 1985). The Alfred-Wegener-Institut of Germany (AWI) carried out airborne magnetic and radio-echo surveys totalling $9000 \mathrm{~km}$ in 1983/84 and Soviet Antarctic Expeditions have, since $1979 / 80$, operated one summer station, from where a considerable network of aeromagnetic and radio-echo lines has been flown. In 1982/83, BAS flew 18000 line kilometres over Ronne Ice Shelf, recording ice thickness and aeromagnetic data; in $1983 / 84$, a further 4000 and, in 1984/85, 5000 line-kilometres were flown.

\section{DATA RELIABILITY}

The total coverage of Ronne Ice Shelf by BAS, some $34000 \mathrm{~km}$, is shown in Fig.2. The navigation systems used have been inertial navigation (1975) and Doppler. Although, by their nature, ice shelves lack point features which can easily be identified and used to fix the track, it is likely

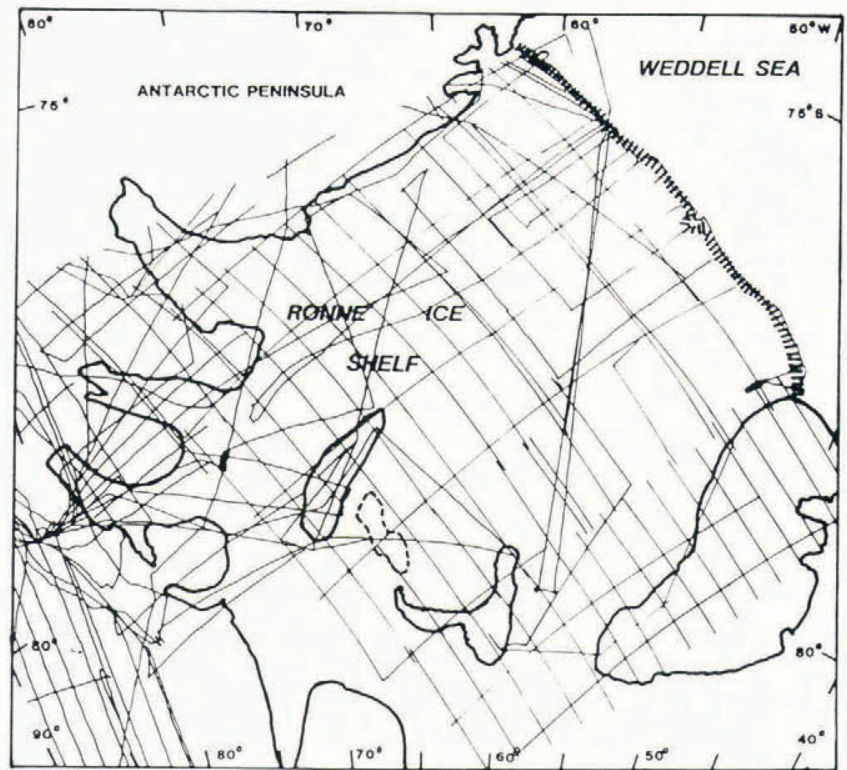

Fig.2. Radio-echo lines flown by BAS over Ronne Ice Shelf, $1975-1985$. 
that all BAS flights since 1975 are accurate to $2 \mathrm{~km}$ or better.

It is possible to measure ice thicknes from a digitised film record to $\pm 10 \mathrm{~m}$ and the majority of discrepancies in thickness, where flights intersect, should be due to small positional errors. All flight intersections, where ice thickness data exist, were examined for consistency. The mean error of intersections was better than $20 \mathrm{~m}$, with a standard deviation of $40 \mathrm{~m}$. However, of the 224 intersecting points, inconsistencies in 30 could be attributed to two 1975 flights, which could not be fixed with the same degree of accuracy and which flew over Rutford Ice Stream, where large thickness gradients mean that a positional error of as little as $1 \mathrm{~km}$ would alter the thickness value appreciably. When these were accounted for, the mean error was $10 \mathrm{~m}$ and the standard deviation $15 \mathrm{~m}$.

Contouring of the data was done by hand, with an interval of $50 \mathrm{~m}$. Some degree of generalisation was necessary, because it is obvious that the ice shelf is extremely complex and even the relatively dense network of flight lines is inadequate to show detail in places.

\section{INTERPRETATION OF ICE FLOW}

A comparison of the map in Fig. 3 with that produced previously (Robin and others, 1983) shows that, while the major features remain unchanged, considerable detail has been added to the overall picture of ice thickness. Fig.4 shows the principal flow lines on Ronne Ice Shelf; they are seen either as surface features on satellite (LANDSAT) imagery or as features in the radio-echo film record which can be traced across several flight lines.

Flow lines indicate that ice, between Berkner Island and Henry Ice Rise, originates from Foundation Ice Stream. In the central part of Ronne Ice Shelf there is a $140 \mathrm{~km}$ wide zone of ice, less than $300 \mathrm{~m}$ thick, which stretches back from the ice front for $350 \mathrm{~km}$. The lateral margins of this ice feature are almost straight and parallel; there seems to be little tendency for the thicker ice on either side to flow into the central area. This feature is related to the rapid thinning over a grounded area between Korff and Henry ice rises, where the ice shelf thins by $500 \mathrm{~m}$ in a distance of less than $30 \mathrm{~km}$. Although there is a major ice stream to the south (Institute Ice Stream), flow lines suggest that the greater part of its ice flows north-westwards between Skytrain and Korff ice rises, where it meets the discharge from Rutford Ice Stream. Both the thickness map (Fig.3) and the flow line map (Fig.4) suggest that some of the ice from Rutford Ice Stream flows across Kershaw Ice Rumples. The flow lines show that little ice comes from Carlson Inlet, which drains a much smaller area than Rutford and Evans ice streams and is less active (Swithinbank, 1977). Extending to the ice front from Fowler Peninsula is a second, remarkably well-defined, thin region separating ice from Evans Ice Stream from that which

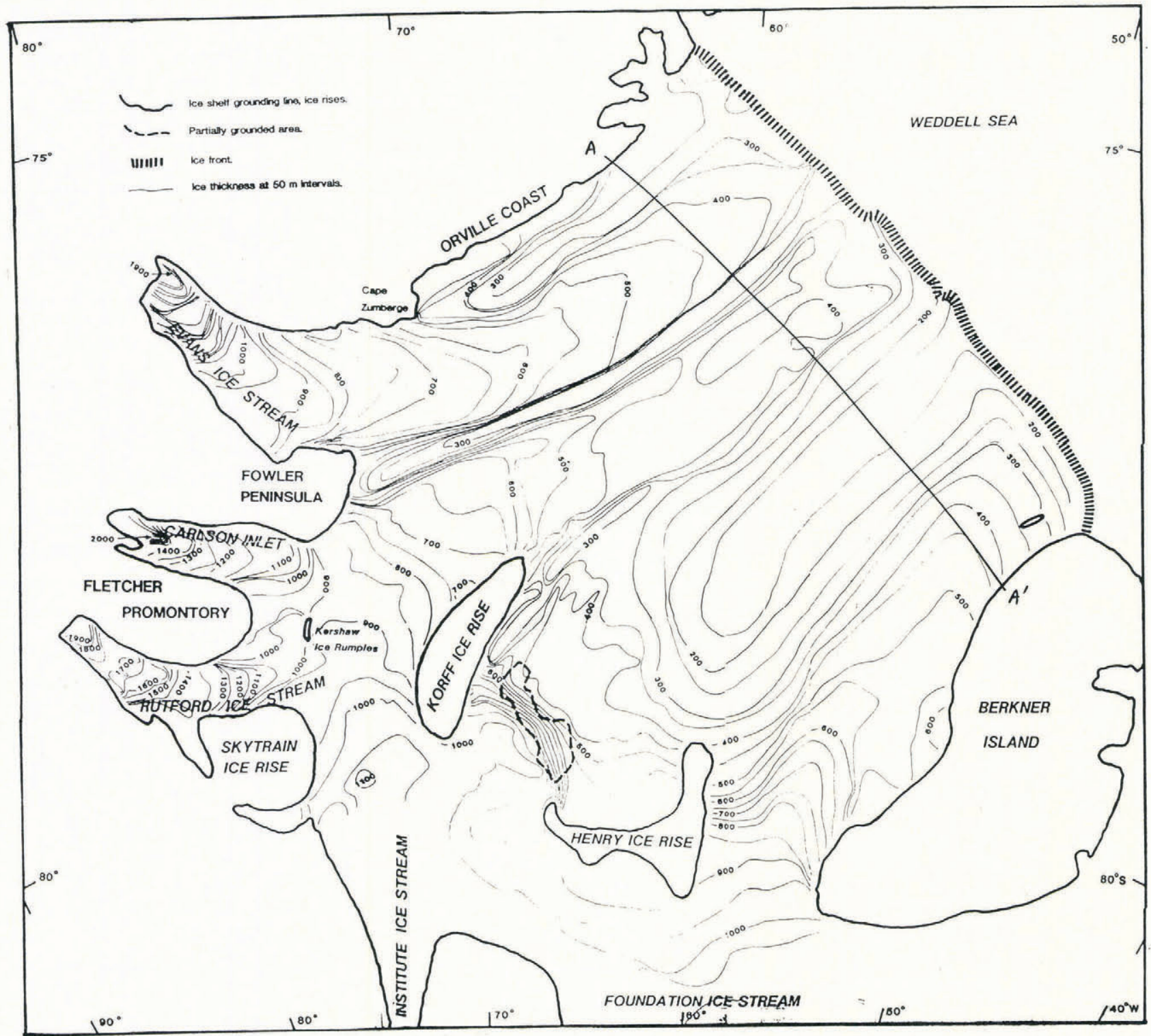

Fig.3. Ice thickness on Ronne Ice Shelf compiled from data gathered from BAS radio-echo surveys. The line A-A' shows the section of flight line for which the film record is shown in Fig.5. 


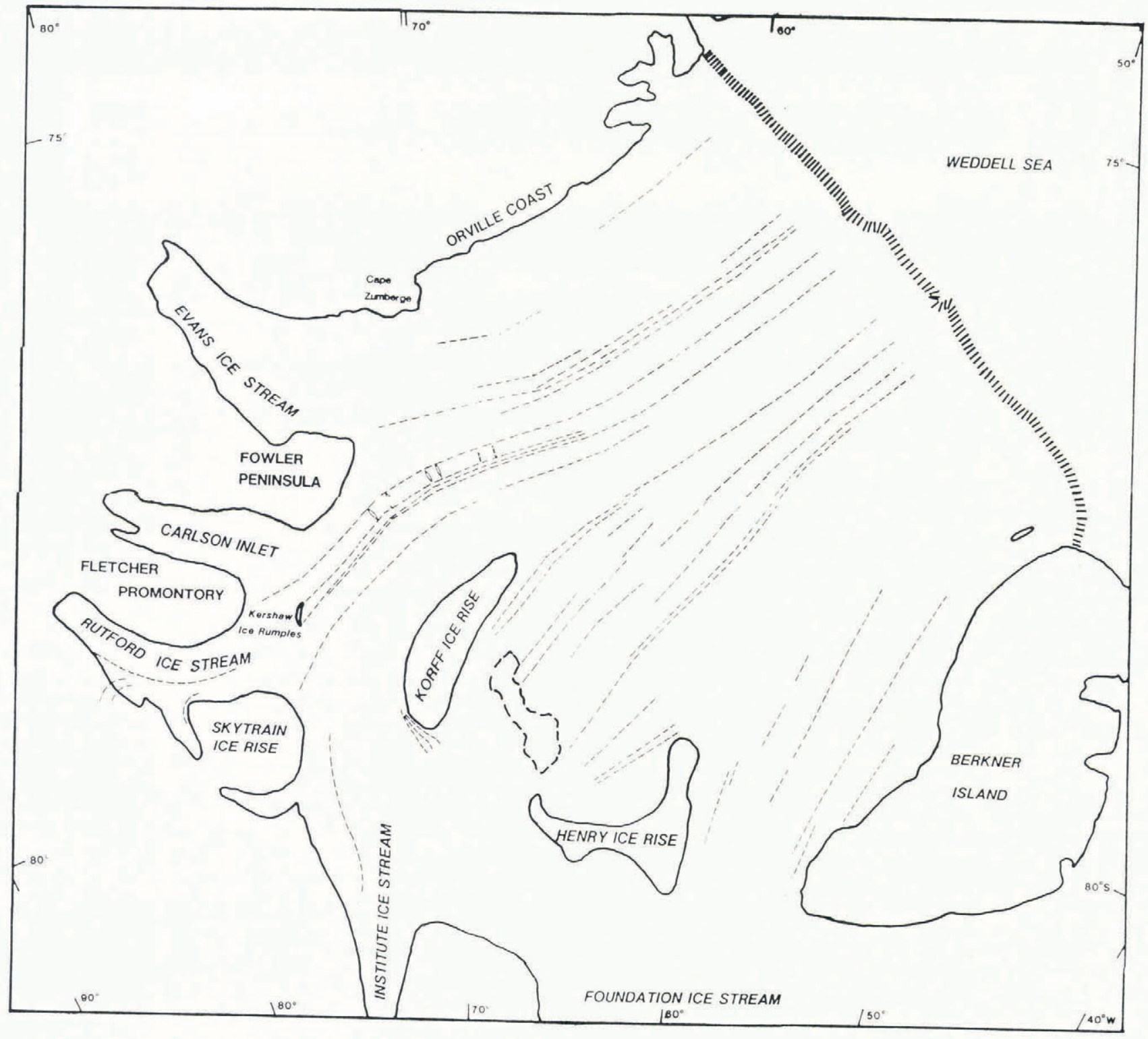

Fig.4. Flow lines on Ronne Ice Shelf, interpreted from satellite images and from features in the radio-echo film record. The six rifts in ice coming from Rutford Ice Stream are shown.

originated in Rutford and Institute ice streams. Some ice from Rutford Ice Stream can be clearly seen as a narrow $(<20 \mathrm{~km})$ lobe of thicker ice, bordering the south-eastern margin of this channel.

Evans Ice Stream flows to Ronne Ice Front as an uncomplicated lobe of ice, with a constant width of about $90 \mathrm{~km}$. Between this ice and the Orville Coast is a thinner area of ice shelf, which appears to be in a flow "shadow" of Cape Zumberge. The thin ice channel, extending to the ice front from Fowler Peninsula, is about $25 \mathrm{~km}$ wide. During oversnow traverses by BAS in $1983 / 84$, a slight depression in the ice shelf elevation was noticed at $77^{\circ} 30$ 's $67^{\circ} \mathrm{W}$; seismic results in this area show a shallower depth to bedrock (B. Herrod, personal communication), indicating a ridge in the bedrock directly underneath this thinner section. Although it is not known whether the ridge extends south-west to Fowler Peninsula, hydrographic surveys along the ice front (Kohnen, 1982) show a rise in bedrock from $600 \mathrm{~m}$ b.s.l. to about $350 \mathrm{~m}$ b.s.l. at the place where the thinner ice reaches the ice front. It is likely that the thinner ice and underlying ridge are related. The ridge may be structural, perhaps the glacially modified continuation of a horst between Evans Ice Stream and Carlson Inlet grabens, or it may be entirely the product of erosion by the respective ice streams during a period of lower sea level.

The flow lines show that there is only a slight convergence of ice towards the centres of the thinner sections. Inferred velocities along the ice streams, calculated by mass-balance arguments (Doake, in press), suggest that lateral strain rates are of the order $10^{-3} \mathrm{a}^{-1}$, which would result in flow lines diverging or converging at only a few degrees.

THIN AREAS IN THE ICE SHELF: BOTTOM FREEZING AND THE NATURE OF THE REFLECTING LAYER

One of the characteristics of radio-echo surveys of ice shelves is that the returned signal is usually very strong because of the high reflection coefficient between ice and sea water. However, Robin and others (1983) noted that all flights over the thin central section downstream of Korff and Henry ice rises tended to produce weak bottom echoes. One of their explanations for this was the freezing-on of a saline ice layer to the base of the ice shelf. The more recent radio-echo surveys by BAS have also found weak echoes over the same area; in places the echo disappears completely.

Thyssen (1985) has noted occasional occurrences of two reflecting layers from $35 \mathrm{MHz}$ radio echo-sounding near Filchner Station. In the central part of the thin area, the depth to the first reflector is about $120 \mathrm{~m}$, of the same order as that published by Robin and others (1983). Further inland from Filchner Station, the bottom reflector becomes very weak and disappears. Thyssen attributes this second reflector to the base of a layer of saline ice. From pressure and radar altimetry recorded on flights by AWI, it appears that the freeboard of this part of the ice shelf is too high 


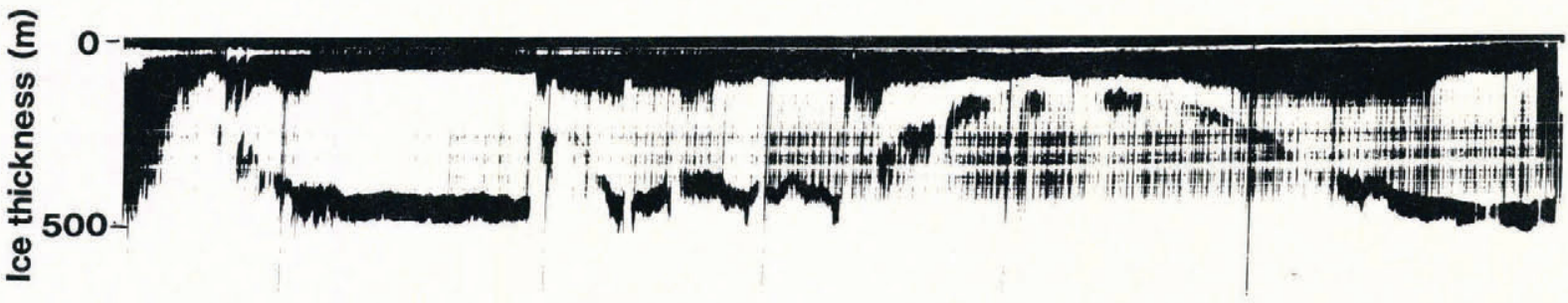

$0 \quad 50 \mathrm{~km}$

Fig.5. Radio-echo film record across Ronne Ice Shelf, along the flight line A-A' shown in Fig.3.

for an equilibrium ice shelf of about $150 \mathrm{~m}$ thickness and he calculates the lower saline layer to be of the order of $200 \mathrm{~m}$ thick, in places.

With our measured system performance of about $160 \mathrm{~dB}$, we expect to have about $60 \mathrm{~dB}$ available to account for reflection and extra impurity absorption losses when flying at $500 \mathrm{~m}$ above a $400 \mathrm{~m}$ thick ice shelf with an average temperature of $-10^{\circ} \mathrm{C}$. Reflection losses can range from $-1 \mathrm{~dB}$ for a smooth, pure ice - sea water boundary down to $-15 \mathrm{~dB}$ for a rough ice - water boundary and can be as low as $-38 \mathrm{~dB}$ for the boundary between glacial and saline ice (Neal, 1979). Absorption of radio-echo signals by saline ice depends on its conductivity and is typically about 25 to 50 times that of polar glacier ice. Signal attenuation may exceed $1 \mathrm{~dB} \mathrm{~m}^{-1}$ and it would take a relatively thin layer of saline ice to occlude an echo completely from the sea-water interface, while still allowing a measurable echo to be received from the top of the saline layer. Because of the pulse length of our equipment (about $25 \mathrm{~m}$ in ice), by the time a second echo from the bottom of a saline layer would have been resolvable, it would be too weak to be detected. For thin layers of saline ice (less than about $5 \mathrm{~m}$ ), although the echo from the bottom of the layer at the ice - water boundary may be stronger than the echo from the top of the saline layer, the echoes could not be resolved.

From the radio-echo surveys undertaken by BAS, there is no firm evidence for or against the freezing-on of a substantial layer of saline ice. A close examination of the film record shows no evidence of a second echo. Even where the ice begins to thin, there is no indication of a lower reflecting layer. However, the length of the first echo may hide the presence of a weak second one.

Also, the echo is not weak everywhere. Fig.5 is the film record for the flight line $A-A^{\prime}$ on Fig.3. There are several, isolated, strong reflections that may be indicative of a fresh, ice - sea water interface. However, strong reflections may be caused by an abrupt change in electrical properties in distances of the order of a wavelength (about $3 \mathrm{~m}$ in ice at $60 \mathrm{MHz}$ ).

An analysis has been made of the relationship between surface elevation (freeboard) and ice thickness for one flight that crosses the thin central area twice. There is no particular cluster of thin ice data points which deviate from the general relationship between surface elevation and ice thickness. However, there is considerable scatter within the data, due to random noise of about $20 \mathrm{~m}$, arising from the combination of pressure and radar altimeters and an unknown systematic error, due to synoptic pressure gradients over the ice shelf.

The freeboard of a fresh ice shelf of about $150 \mathrm{~m}$ thickness should be about $19 \mathrm{~m}$ (assuming $\bar{\rho}_{\mathrm{j}}=0.9 \mathrm{Mg} \mathrm{m}$ and $\rho_{\mathrm{w}}=1.028 \mathrm{Mg} \mathrm{m}{ }^{-3}$ ). The addition of a further $200 \mathrm{~m}$ of saline ice, $\bar{\rho}_{\mathrm{i}}=0.927 \mathrm{Mg} \mathrm{m} \mathrm{m}^{-3}$ (for a salinity of $4 \%$ at $-3^{\circ} \mathrm{C}$ (Shabtaie and Bentley, 1982), would give an average ice density $\bar{\rho}_{\mathrm{i}}$ of $0.915 \mathrm{Mg} \mathrm{m} \mathrm{m}^{-3}$ and the freeboard would be $38 \mathrm{~m}$. If the salinity is as high as $15 \%$, equivalent to a density of $0.953 \mathrm{Mg} \mathrm{m}^{-3}$, the average ice density $\bar{\rho}_{\mathrm{i}}$ is $0.930 \mathrm{Mg} \mathrm{m}^{-3}$ and the expected freeboard $33 \mathrm{~m}$. Therefore, the difference in surface elevation between observed and theoretical values may range from $19 \mathrm{~m}$ to $14 \mathrm{~m}$. Both these figures are well within the error to be expected in calculating surface elevations from the aircraft altimeters. Therefore, our altimetry data cannot show whether the ice in the central section is thicker than as shown in Fig.3.

Although brine has been found to penetrate laterally for up to half a kilometre inland from the ice front (Thyssen, 1985), this is an unlikely mechanism for an internal reflecting layer of the size involved here. If infiltration occurred through the bottom crevasses, which penetrated upwards to the permeable ice expected at about $40 \mathrm{~m}$ depth, it would spread horizontally at about that depth everywhere, whereas the reflecting layer is clearly dome-shaped, rising, without any significant break, from about 400 to $150 \mathrm{~m}$. The density profile parameters, measured on Rutford Ice Streams, indicate that the porous firn to ice transition density of $0.82 \mathrm{Mg} \mathrm{m}^{-3}$ is reached at about $40 \mathrm{~m}$ depth below the surface. The equivalent ice shelf thickness, for a freeboard of $40 \mathrm{~m}$, is around 250 to $300 \mathrm{~m}$. For ice shelf thicker than this, the porous firn would be above sea-level and lateral penetration would not be expected.

\section{CONCLUSION}

We conclude that, while there is no radio-echo evidence for the freezing-on of a substantial (up to $200 \mathrm{~m}$ ) layer of saline ice under the central part of Ronne Ice Shelf, there is no evidence that excludes the possibility. It is interesting that there is a similar significant decrease in echo strength on flights over the thin area extending from Fowler Peninsula. Some bottom freezing might be expected there also, for the same reason, but it is possible that the bedrock topography produces a different pattern of oceanic circulation. For example, topographic Rossby waves, excited by the ridge, could lead to strong currents and significant mixing in the sub-ice waters, increasing the heat transfer to the base of the ice shelf (MacAyeal, 1984). Like its much larger counterpart, this thinner area shows isolated strong reflections that may indicate local basal melting. This is an area of complex interactions and the issue of basal melting or freezing cannot be resolved with the present data. If there should prove to be saline ice under the thin ice areas, then the contour map in Fig.3 would be interpreted as showing the thickness of the glacier ice. Perhaps the closest analogue is Amery Ice Shelf, where a basal layer of saline ice $150 \mathrm{~m}$ thick has been reported (Morgan, 1972). Although frozen-on sea ice is believed to underlie parts of Ross Ice Shelf, there are no reports of thicknesses much in excess of the $6 \mathrm{~m}$ found at the $\mathrm{J} 9$ drill hole (Zotikov and others, 1980; Neal, 1979). We await drilling, to confirm the ice thickness and structure of Ronne Ice Shelf.

\section{ACKNOWLEDGEMENTS}

We would like to thank all those involved in the collection and processing of the data, especially George Musil, who was responsible for the collection of the majority of the ice thickness data in $1982 / 83$ and David Vaughan, who helped to process the data in Cambridge. 


\section{REFERENCES}

Doake C S M 1985 Antarctic mass balance: glaciological evidence from Antarctic Peninsula and Weddell Sea sector. In Meier M F (ed) Glaciers, ice sheets and sea level: effect of a CO2-induced climatic change. Washington, DC, National Academy Press: 197-209

Doake C S M In press Some aspects of the flow of Ronne Ice Shelf. In Oerlemans J, Veen $\mathrm{C} J$ van der (eds) The dynamics of the West Antarctic ice sheet. Dordrecht, Reidel

Doake C S M, Crabtree R D, Dalziel I W D 1983 Subglacial morphology between Ellsworth Mountains and Antarctic Peninsula: new data and tectonic significance. In Oliver R L, James P R, Jago J B (eds) Antarctic earth science. Cambridge etc, Cambridge University Press: $270-273$

Drewry D J, Jordan S R, Jankowski E J 1982 Measured properties of the Antarctic ice sheet: surface configuration, ice thickness, volume and bedrock characteristics. Annals of Glaciology 3: 83-91

Jankowski E J, Drewry D J 1981 The structure of West Antarctica from geophysical studies. Nature 291(5810): $17-21$

Kohnen H 1982 Glaciological investigations in the frontal zone of the Filchner and Ronne ice shelves. Annals of Glaciology 3: 160-165

Kohnen H 1985 (comp) Filchner-Ronne-Ice-Shelf Programme. Report No 1 (1984). Bremerhaven, Alf red-Wegener-Institute for Polar Research

MacAyeal D R 1984 Numerical simulations of the Ross Sea tides. Journal of Geophysical Research 89(C1): $607-615$

Morgan V I 1972 Oxygen isotope evidence for bottom freezing on the Amery Ice Shelf. Nature 238(5364): 393-394

Neal C S 1979 The dynamics of the Ross Ice Shelf revealed by radio echo-sounding. Journal of Glaciology 24(90): 295-307

Robin G de Q, Doake C S M, Kohnen H, Crabtree R D, Jordan S R, Möller D 1983 Regime of the Filchner-Ronne ice shelves, Antarctica. Nature 302(5909): $582-586$

Shabtaie S, Bentley C R 1982 Tabular icebergs: implications from geophysical studies of ice shelves.
Journal of Glaciology 28(100): $413-430$

Swithinbank C W M 1977 Glaciological research in the Antarctic Peninsula. Philosophical Transactions of the Royal Society of London Ser B 279(963): 161-183

Thyssen F 1985 First results from Polar-2-measurements on the Filchner and Ekström ice shelves. In Kohnen $\mathrm{H}$ (comp) Filchner-Ronne-Ice-Shelf-Programme. Report No 2 (1985). Bremerhaven, Alfred-Wegener-Institute for Polar Research: 131-132

Zotikov I A, Zagorodnov V S, Raikovsky Ju V 1980 Core drilling through the Ross Ice Shelf (Antarctica) confirmed basal freezing. Science 207(4438): 1463-1465 